\title{
Actinemys marmorata (Baird and Girard 1852) - Western Pond Turtle, Pacific Pond Turtle
}

\author{
R. Bruce Bury ${ }^{1}$ and David J. Germano² \\ ${ }^{1}$ U.S. Geological Survey, Forest and Rangeland Ecosystem Science Center, \\ 3200 SW Jefferson Way, Corvallis, Oregon, 97331 USA [buryb@usgs.gov]; \\ ${ }^{2}$ Department of Biology, California State University at Bakersfield, \\ Bakersfield, California 93311-1022 USA [dgermano@csub.edu]
}

Summary. - Actinemys marmorata (Family Emydidae) occurs in the Pacific States of North America from Baja California Norte north through Washington and, possibly, into southernmost British Columbia, Canada. Recent genetic studies indicate the presence of four groups or clades within the species, although historically there were two recognized subspecies. The species appears to be declining in abundance in the northernmost and southernmost portion of its range, but not in the core of its range from central California to southern Oregon. The primary threats are loss and alteration of both aquatic and terrestrial habitats. These losses fragment remaining populations and, perhaps, magnify the effects of introduced species through predation, competition, and epidemic disease(s). Historically, A. marmorata was collected for the food and pet trades. Most states now protect the species and, in Washington, it is listed as Endangered. Research is ongoing on many aspects of the species' ecology, but not all of the studies are published. Greater effort is needed to protect and manage aquatic habitats as well as nesting and overwintering sites in adjacent uplands.

Distribution. - Canada (?); Mexico; USA. Pacific States of North America from Baja California Norte, Mexico, north through Washington and, possibly, into southernmost British Columbia, Canada.

SyNONYMY. - Emys marmorata Baird and Girard 1852; Actinemys marmorata; Clemmys marmorata; Geoclemmys marmorata; Chelopus marmoratus; Melanemys marmorata; Clemmys marmorata marmorata; Actinemys marmorata marmorata; Emys marmorata marmorata; Emys nigra Hallowell 1854; Clemmys wosnessenskyi Strauch 1862; Geoclemmys wosnessenskyi; Clemmys hesperia Hay 1903; Clemmys marmorata pallida Seeliger 1945; Actinemys marmorata pallida; Emys marmorata pallida.

SubSPECIES. - None currently recognized, previously two: $A$. $m$. marmorata (Northern Pacific Pond Turtle) and A. m. pallida (Southern Pacific Pond Turtle). Genetic data suggest four phylogenetic clades.

Status. - IUCN 2007 Red List: Vulnerable (VU A1cd) (assessed 1996, needs updating); CITES: Not Listed; US ESA: Not Listed.

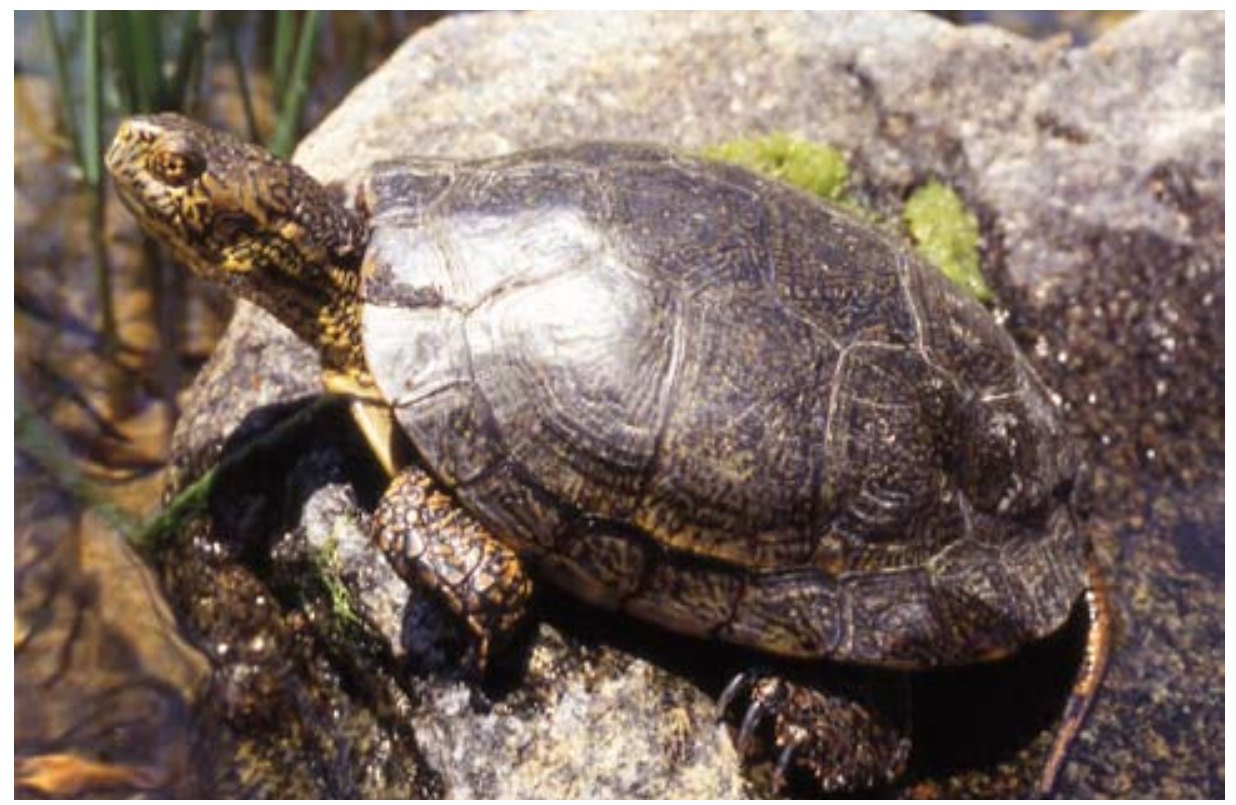

Figure 1. Adult female Actinemys marmorata from San Mateo Creek, Camp Pendleton, San Diego Co., California, USA. Photo by Dan C. Holland. 


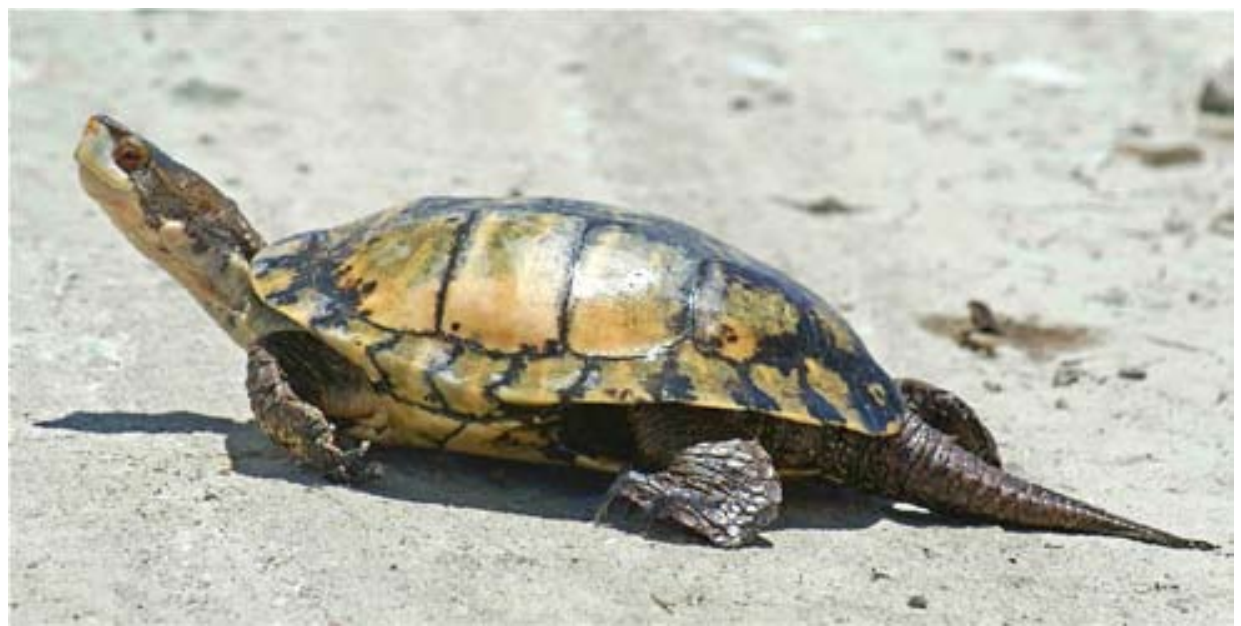

Figure 2. Adult male Actinemys marmorata from Fresno, San Joaquin Valley, California, USA. Photo by David J. Germano.

Taxonomy. - The phylogenetic relationships of the western pond turtle, Actinemys marmorata, are in a state of flux. Recent evidence suggests that the species is distinct from the other three species of the former group Clemmys in eastern North America (Bickham et al. 1996; Feldman and Parham 2001; Holman and Fritz 2001). Feldman and Parham (2002) and Parham and Feldman (2002) presented evidence that the western pond turtle should be placed in the genus Emys, along with the European pond turtle (Emys orbicularis) and the Blanding's turtle (Emys [= Emydoidea $]$ blandingii), and this view has been adopted by others (Spinks et al. 2003; Spinks and Shaffer 2005). In contrast, Holman and Fritz (2001) and Stephens and Wiens (2003) believed that the western pond turtle is not closely related
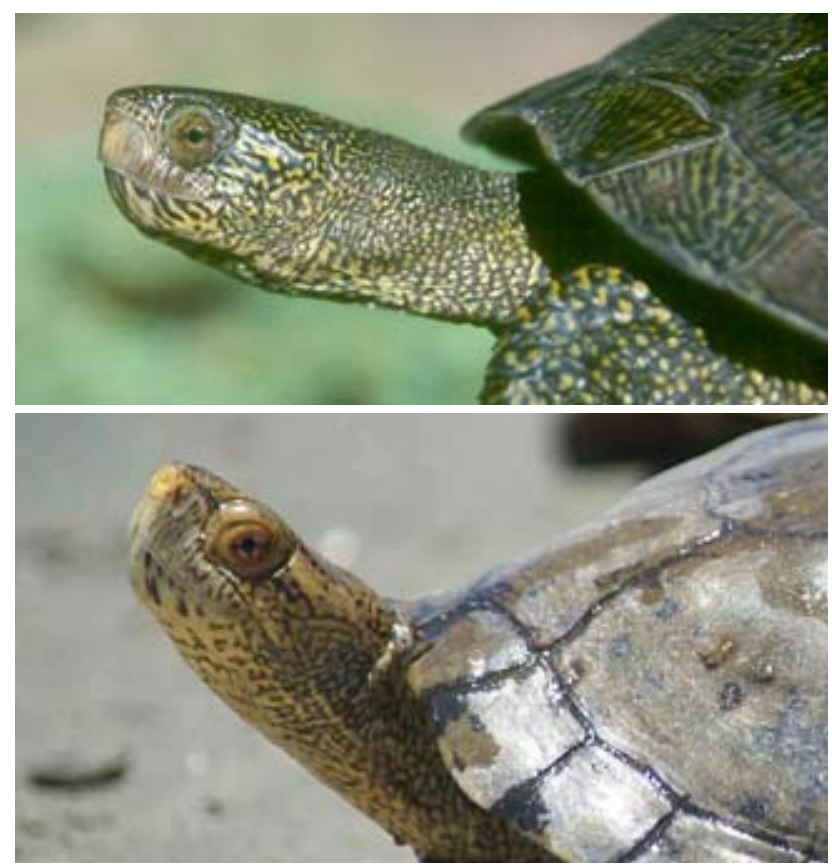

Figure 3. Top: Adult female Actinemys marmorata from Whiskeytown National Recreation Area, Shasta Co., California, USA. Photo by R. Bruce Bury. Bottom: Adult female A. marmorata from Fresno, San Joaquin Valley, California, USA. Photo by David J. Germano. to any extant species and should be placed in its own genus, Actinemys. The Turtle Taxonomy Working Group (2007) recorded it as "Emys or Actinemys marmorata Baird and Girard 1852 [formerly in Clemmys]."

The genus Actinemys is used in both of the most recent standarized names of North American herpetofauna (Collins and Taggart 2002; Iverson et al. 2008) and globally (Fritz and Havas 2007), which we follow here.

The first specimens of A. marmorata were collected in 1841 in the vicinity of Puget Sound (Washington) and described by Baird and Girard (1852) as Emys marmorata. Emys nigra was described by Hallowell (1854) from "Posa (Poso) Creek, Lower California," which is in Kern County in the Central Valley of California (Bury, 1970), but this taxon has not been recognized recently. Seeliger (1945) described two subspecies: the northern Pacific pond turtle (Clemmys $[=$ Actinemys $]$ marmorata marmorata $)$ and the southern Pacific pond turtle (Clemmys [= Actinemys] $\mathrm{m}$. pallida). The northern subspecies has a relatively large inguinal scute compared to a smaller or no inguinal scute in the southern subspecies. In A. m. marmorata, the throat is light and contrasts with the darker sides of the head and neck; whereas A. m. pallida has a more uniform coloration of the throat and neck, often with dark vermiculations (Fig. 1). A broad range of intergradation occurs from the American River south through the San Joaquin Valley, California (Seeliger 1945; Stebbins 2003).

Based on morphology, Holland (1992) found three groups in the taxon: a Columbia River form; a northern form occurring from Puget Sound to central California; and a southern form along the central coast of California south to Baja California. However, there are no published descriptions of these taxa. Using DNA fingerprinting, Gray (1995) reported low levels of genetic variation within and among several populations throughout the range, although significant differences were present between northern and southern populations.

Recently, Spinks and Shaffer (2005) reported genetic differences indicating four un-named clades within $A$. marmorata, with the following distributions: 1) from the 
Traverse Mountains of southern California south into Baja California Norte; 2) the San Joaquan Valley and adjacent foothills; 3) Ventura and Santa Barabara counties in central coastal California; and 4) all the remaining populations to the north. These data suggest considerable genetic fragmentation within the species, especially in the southern half of the range. The new groupings do not follow the pattern of the earlier described subspecies, and we suggest waiting for additional data before these new groups are recognized as taxonomic units.

Description. - Male A.marmorata can be distinguished from females usually by a size of $120 \mathrm{~mm}$ carapace length (in some populations by $110 \mathrm{~mm}$ ), when individuals are considered adults. Generally, adults range in size from 140-190 mm CL (Bury 1995; Lubcke and Wilson 2007). Hatchlings are 20-30 mm CL (Storer 1930; Feldman 1982; Lovich and Meyer 2002). Shell metrics appear to be related to geographic location, water temperatures and, perhaps, diet (Lubcke and Wilson 2007). The shell is low and broad, generally widest posterior to the middle (across the 8th marginal). Turtles in cool flowing waters, such as streams, may be more elongate than those living in standing waters, such as ponds and lakes (Lubcke and Wilson 2007). The carapace in adults is smooth and lacks a keel or serrations. Vertebral scutes are broader than long, and the first touches four marginals and the nuchal (Carr 1952; Ernst et al. 1994). The hind foot is webbed to the base of the claws (Ernst et al. 1994). The carapace coloration is usually dark brown or dull yellow-olive, with or without darker streaks or vermiculations. Many males in the Central Valley of California develop distinct yellow coloring on all or part of each marginal and costal scutes of the carapace (Fig. 2). The plastron is cream or light-yellow in color, sometimes with dark areas on parts of the scutes.

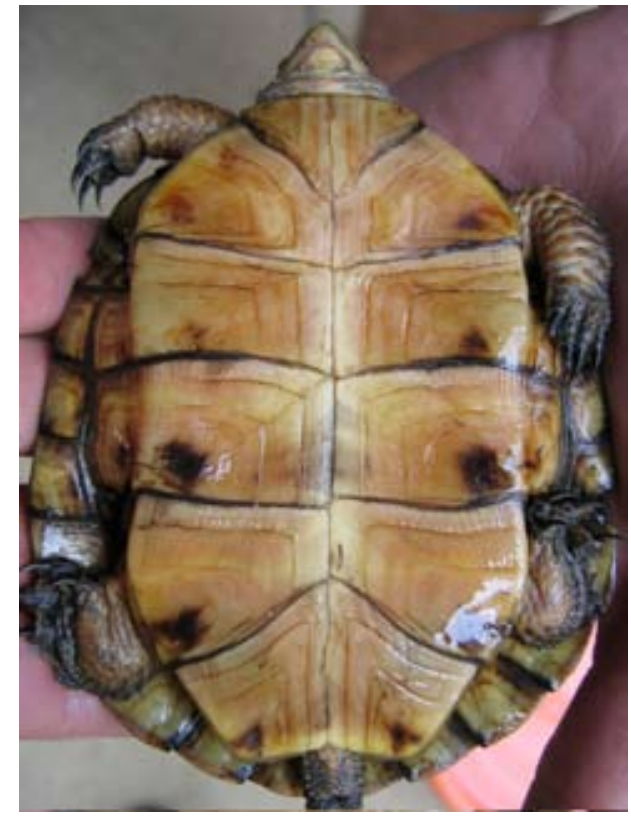

Figure 4. Juvenile Actinemys marmorata showing growth rings; from Klamath Lake region, southern Oregon, USA. Photo by R. Bruce Bury.

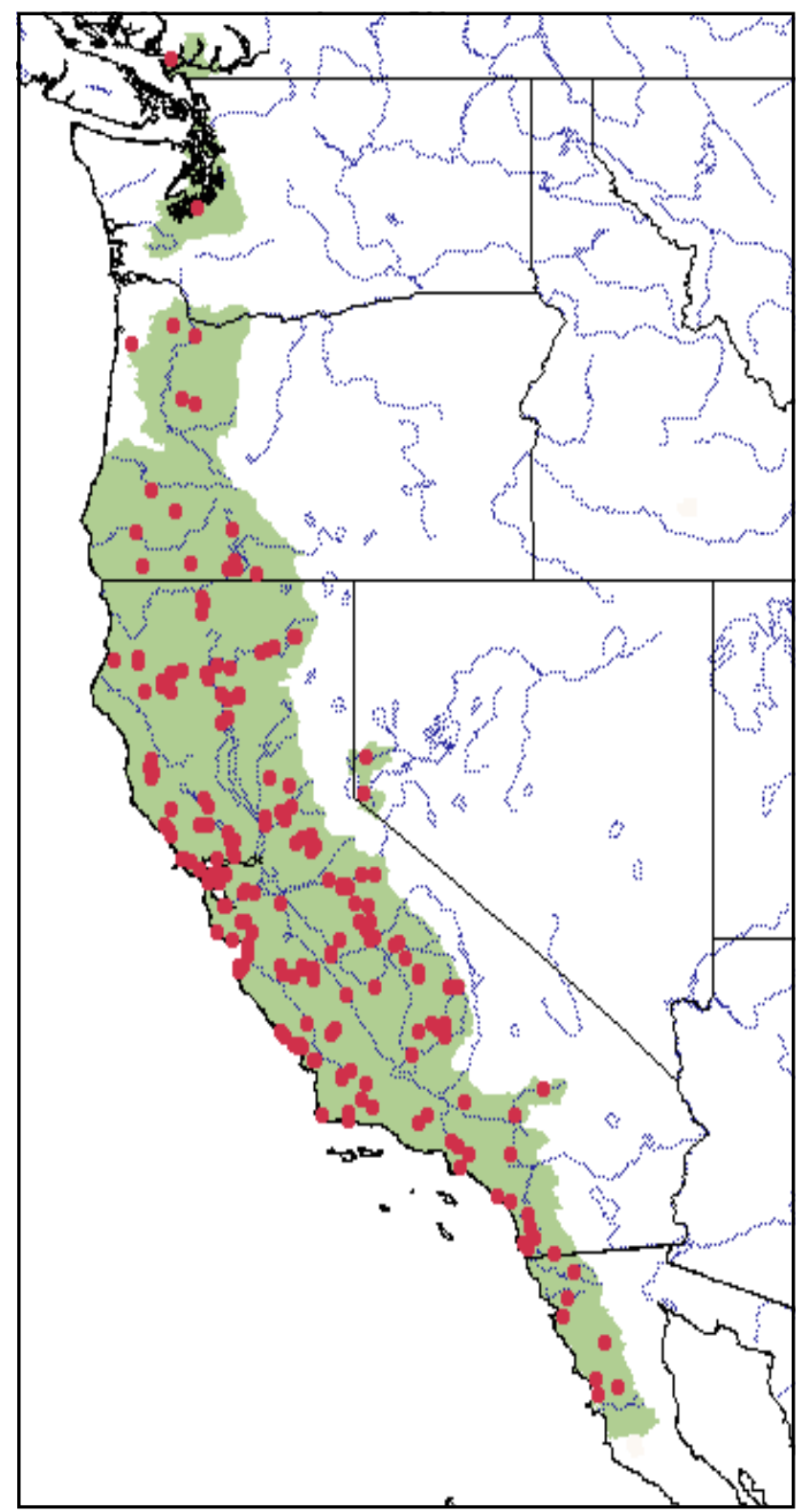

Figure 5. Distribution of Actinemys marmorata in western North America. Red points $=$ museum and literature occurrence records based on Iverson (1992) plus more recent and authors' data; green shading $=$ projected distribution based on GIS-defined hydrologic unit compartments (HUCs) constructed around verified localities and then adding HUCs that connect known point localities in the same watershed or physiographic region, and similar habitats and elevations as verified HUCs (Buhlmann et al., unpubl. data), and adjusted based on authors' data.

Males differ from females in size, shell, and other features. Males have a concave plastron in the femoral region, while the plastron in females tends to be flat. When the tail is extended, the cloaca is usually posterior to the edge of the carapace in males, but usually at or anterior to the margin in females. In males, the tail is thicker, the head slightly larger, and the snout more angular than in females. Males usually have light-colored throats that become lighter with age (Fig. 2). Most females (Fig. 3) have a brown or yellow-brown throat with moderate to extensive flecking, essentially keeping the pattern and coloration of juveniles 
(Fig. 4). Males average a larger size than females in most populations, and reach a larger maximum size $(241 \mathrm{~mm}$ CL) than females (192 mm CL; Lubcke 2006).

Although A. marmorata is the only native freshwater turtle from northern Baja California Norte to the central Willamette Valley in Oregon, it occurs with the western painted turtle (Chrysemys picta bellii) in northern Oregon and western Washington. The painted turtle is distinctively marked with a reddish plastron, olive-green or blackish-green carapace, and bright red and yellow stripes on the neck and legs. Actinemys marmorata is easily differentiated from the painted turtle; however, field identification of turtles is becoming complicated with the introduction of non-native turtles (Bury and Luckenbach 1977; Jennings 1987; Bury, in press). In particular, melanistic red-eared sliders (Trachemys scripta elegans) viewed from a distance may resemble adult $A$. marmorata.

Distribution. - Actinemys marmorata occurs from northern Baja California Norte, Mexico, north to the Puget Sound region of Washington, USA (Bury 1970; Nussbaum et al. 1983; Iverson 1986; Stebbins 2003) (Fig. 5). In Baja, they are only known from the Pacific slopes of the San Pedro Martir (Smith and Smith 1979; Welsh 1988; Lovich et al. 2007). Isolated populations occur in the Mojave River in the western Mojave Desert, California; the Carson River in Nevada; east of the Cascade Mountains in or near the Columbia River in Oregon-Washington; and the Puget Sound area in Washington. Records in the Truckee, Carson, and Humboldt rivers in western Nevada (LaRivers 1942; Banta 1963) are likely turtles originally imported as a source of human food (Cary 1889). Their genetic relationships are under study (Spinks and Shaffer 2005). There are other outlying locality reports that may represent introduced individuals or populations, or are mis-identified or mis-labeled specimens: one male collected along Canyon Creek, Grant County, Oregon (Black and Storm 1970); one juvenile taken in 1894 from along the Snake River, Jerome County, Idaho (Slater 1962); and two turtles collected in coastal British Columbia, Canada (Gregory and Campbell 1984; Matsuda et al. 2006).

Habitat and Ecology. - Actinemys marmorata occurs in a variety of permanent and intermittent aquatic habitats, including rivers, streams, lakes, ponds, marshes, vernal pools, and human-constructed environments such as ponds associated with waste-water, stock, and logging operations (Storer 1930; Germano and Bury 2001; Buskirk 2002). Prior to human settlement, there were few natural ponds or lakes within the range of the species, but some notable exceptions include the Klamath Lakes in Oregon and California, Clear Lake in northern California, the Tulare-Buena Vista-Kern Lake complex in the southern San Joaquin Valley of California, and back-dune ponds in coastal sand-dune complexes in central California. Streams, rivers, and artificial small ponds are the most common habitats for this species. Because much of the range of A. marmorata has a Mediterranean climate (mild, wet winters; dry, hot summers), many natural watercourses and ponds are intermittent or exhibit greatly reduced flows in summer. Although considered an aquatic form, this turtle may spend considerable time on land every year. Based on radio-tracking studies, some turtles occur on land up to seven months out of each year (Reese and Welsh 1997; Rathbun et al. 2002). Turtles may aestivate in upland areas, but physiological studies are needed to confirm this. Turtles may also travel across terrestrial habitats at distances in excess of $1 \mathrm{~km}$ from water.

Habitats with abundant basking sites, underwater refugia, and standing or slow-moving waters are preferred conditions for this species. Along a stream in northern California, there was a high correlation between turtle abundance and the number of available basking sites such as logs or boulders (Bury 1972). Turtles in streams often take refuge in plunge pools, perhaps because these pools provide deep water for escape and lack swift currents. Turtles aggregate in these microhabitats at densities often several times that observed in swifter moving sections of creeks. In rivers, the species is most abundant in slower waters (e.g., pools) that are deep and have basking sites (Reese and Welsh 1998a). Emergent basking sites may include mats of vegetation, floating logs, or mud banks just above the water line. Actinemys marmorata in all habitats also engages in aquatic basking by moving into the warm thermal environment on top of submerged mats of vegetation or in shallow water. Basking sites can become crowded with turtles and, at these times, turtles may display frequent aggressive interactions (pushing, open-mouth gestures, biting) among all size and sex classes (Bury and Wolfheim 1979; Holland 1985a).

The species is omnivorous and a dietary generalist (Evenden 1948; Holland 1985a, b; Bury 1986; Goodman and Stewart 1998), feeding on the larvae of dragonflies, mayflies, stoneflies, caddisflies, midges, beetles, and other insects, as well as crayfish and other aquatic invertebrates (Holland 1985a; Bury 1986). Native fishes and anurans also are eaten, but these are minor items $(<10 \%)$ in the diet and may represent animals scavenged when dead or weakened (Holland 1985a; Bury 1986). Further, they may eat small to large amounts of vegetation, including filamentous green algae, tule and cattail roots, water lily pods, and alder catkins (Holland 1985a; Bury 1986). Actinemys marmorata can employ neustophagia (modified gape-and-suck feeding) to obtain small prey items (such as Daphnia) off the water surface or in the water column (Holland 1985b; Bury 1986).

Actinemys marmorata occupies relatively small home ranges in stream habitats and moves over large areas in other habitats (Bury 1979; Goodman and Stewart 2000). In a California stream during one summer, males had a home range that averaged 1 ha of water surface, while the home range size over the yearly activity period (mostly summer) of females averaged only 0.3 ha and juveniles 0.4 ha (Bury 1972, 1979). Movements up and down this stream (based on mark-recapture from one summer to the next) differed 
between adult sexes (mean values): males, $367 \mathrm{~m}$; females $149 \mathrm{~m}$; juveniles $145 \mathrm{~m}$. Actinemys marmorata occasionally moves long distances within or among watercourses; a few turtles moved over $1 \mathrm{~km}$ in a three-year period, and one marked turtle moved more than $1.5 \mathrm{~km}$ in a two-week period (Bury 1972).

In the wild, A. marmorata are usually wary and secretive. Most individuals rapidly depart basking sites when disturbed by either visual or auditory stimuli of people (e.g., waving an arm, shouting) at distances of over $100 \mathrm{~m}$. When resting or hiding, turtles often seek underwater refugia such as under rocks, boulders, root masses, in undercut banks, or under other debris, where they wedge themselves into the most inaccessible crevices available. Turtles disturbed in shallow water often remain motionless, or attempt to hide in or under floating vegetation or occasionally dig into the substrate.

Individuals appear to grow more slowly in the northern half of their range than towards the south. In northern California, males display secondary sexual characteristics at 110-120 mm CL (Bury 1972) and are 5-9 yrs old, and females are reproductive at 7-10 yrs old (Germano and Bury 2001). Females in the southern part of the range may reproduce at 4-8 yrs of age (Germano and Rathbun, in press; D. Germano, unpubl. data).

Like most turtle species, ages of young A. marmorata can be determined using scute annuli (Bury and Germano 1998; Germano and Bury 1998) (Fig. 4). At warmer sites, scute annuli are discernible for 6-10 yrs; whereas, at colder sites annuli form up to 16 yrs (Bury and Germano 1998). However, mark-recapture is the only way to age older individuals. Adult turtles may reach an age of more than 40 yrs in the wild. For example, we have recaptured adult turtles 30 yrs after they were first marked (Bury 1972, unpubl. data). One turtle marked as an adult in central Oregon in 1958 was recaptured in 1993 (D. Holland, unpubl. report). However, the relative proportion of "old" turtles in most populations appears low (Germano and Bury 2001). Most A. marmorata populations that we have studied consist of equal numbers of males and females and a large proportion of adult turtles (> $120 \mathrm{~mm} \mathrm{CL}$ ). However, most of these populations have a large proportion of turtles $<12 \mathrm{yrs}$ of age, often with a number of turtles in the 1-4 yr age group (Germano and Bury 2001; Germano and Rathbun, in press; D. Germano and B. Bury, unpubl. data).

Parasites include external leeches and internal nematodes (Ingles 1930; Thatcher 1954; Bury 1986), although external parasites are rare. Hundreds of nematodes may occur in the intestine of a single individual (Bury 1986). Colonial protozoans may attach to some turtles in warm waters (Germano 2000). Predators include many carnivorous mammals (Bury 1972; Manning 1990): river otter, mink, raccoon, gray fox, coyote, and black bear. Avian predators may include bald eagle, osprey, great blue heron, and gulls (Holland 1994). Introduced bullfrogs (Lithobates [= Rana] catesbeiana) and fishes such as largemouth bass (Micropterus salmoides) are predators (Moyle 1973;
Nussbaum et al. 1983) on young turtles, but their effect on populations, if any, is unknown, and the two species often co-exist (Germano and Bury, pers. obs.).

The activity cycle of $A$. marmorata is largely determined by temperature (Bury 1972; Reese and Welsh 1998b; Rathbun et al. 2002). The species becomes most active when water temperatures are above $15^{\circ} \mathrm{C}$. Turtles may be active year-round in warmer areas, but on a reduced level in the late fall and winter. Courtship and mating behavior has been observed from February-November (Holland 1988). Turtles have been observed emergentbasking on warm days in February, and have even been observed and radio-tracked moving under the ice in frozen montane lakes in central Oregon when water temperatures were approximately $1-2^{\circ} \mathrm{C}$ (D. Holland, unpubl. report). Turtle activity is usually observed throughout the day, but nocturnal activity may occur during the summer (S. Cross, pers. comm.).

During atmospheric basking, adult turtles elevate and maintain body temperatures near $32^{\circ} \mathrm{C}$ through a repertoire of thermoregulatory behaviors (Bury 1972, 1979; Holland 1985a). They expose the shell to direct sun (heating) and then may dunk the head, limbs, or entire body in water for cooling. Turtles often rotate the body axis, extend or retract the head and/or limbs, and change diurnal patterns (time of emergence). In northern California, most atmospheric basking occurs early in the day (0900-1100 hrs) when water temperatures are low; many turtles hide or rest during warmer parts of the day (Bury 1972). Actinemys marmorata also may raise their body temperature by burying themselves in warm sand (Rathbun et al. 2002) and under algal mats that are much warmer than the surrounding water (Bury and Germano, pers. obs.; G. Rathbun, pers. comm.).

Actinemys marmorata display a "mixed-mode" strategy when overwintering. Although some animals may be active on a year-round basis, other animals may enter overwintering sites in October-November and reemerge in March-April. In most slack-water habitats, many turtles appear to overwinter in the substrate or in undercut areas along the bank (D. Holland, unpubl. report). Turtles may aggregate in a small area; 43 animals were found in an area of approximately $1 \mathrm{~m}^{2}$ in a pond in western Oregon (D. Holland, unpubl. report). Turtles from flowing-water habitats often leave the watercourse in late fall and move up to $480 \mathrm{~m}$ into upland habitats, where they burrow into leaf litter, usually under trees or shrubs (Rathbun et al. 1992; Reese and Welsh 1997). Further, they may emerge from these sites to bask on warm days, and may move among several overwintering sites over the course of several months. Turtles will move to upland sites when waters disappear in streams (G. Rathbun, pers. comm.).

The temperature of egg development affects sex determination in many species of chelonians (Vogt and Bull 1982), and A. marmorata eggs exposed to high temperatures $\left(>27^{\circ} \mathrm{C}\right)$ result in a higher proportion of female hatchlings (Ewert et al. 1994). Some females in this species display some nesting-area fidelity (Goodman 
1997a; K. Beal, unpubl. data). Females are noted for long overland treks to deposit eggs, moving as much as 402 $\mathrm{m}$ away from water and up to $90 \mathrm{~m}$ in elevation above it (Storer 1930; Rathbun et al. 1992). However, most nests are within $50 \mathrm{~m}$ of the edge of water (Holland 1994).

Clutch size varies from 2-13 eggs, and mean clutch size is from 4.5 to 7.3 eggs, depending on location (Feldman 1982; Rathbun et al. 1992; Goodman 1997a; Pires 2001; Lovich and Meyer 2002; Germano and Rathbun, in press). Females can produce two clutches in one season (Goodman 1997b; Pires 2001; Lovich and Meyer 2002; Germano and Rathbun, in press), and some may produce three clutches in the Central Valley of California (Germano, unpubl. data). Eggs of A. marmorata are off-white in color, elliptical-oval in shape, and range from 32-42 $\mathrm{mm}$ long and 18-25 mm diameter. Mass of eggs range from 7-11 g. The egg shell is hard or shelled with a "bone-china" texture. The time from ovulation of eggs to deposition in a nest is unknown. Incubation time ranges from 73-132 days under artificial conditions (Lardie 1975; Feldman 1982) and from 94-122+ days in the wild (D. Holland, unpubl. report; Goodman 1997a). Hatchlings from northern and central California northward overwinter in the nest (Reese and Welsh 1997; Rathbun et al. 2002).

Populations can reach high densities. Bury (1979) reported densities of approximately 400 turtles/ha in a stream population. Some small ponds may have high densities of turtles equal to or exceeding this level (Holland 1994), but turtles tend to aggregate in shrinking bodies of water during late summer and droughts (Storer 1930; R. Bury, pers. obs.). The largest populations of $A$. marmorata occur in Mediterranean-climate areas where there are warm to hot summers, but the same conditions often result in scarce surface water due to increased evaporation rates and lack of precipitation in a relatively long dry season. In most areas, the turtle occurs in disjunct populations over large areas (e.g., aggregations of turtles along long segments of rivers and streams or in isolated ponds or lakes).

Population Status. - The species occurs in many areas and often is abundant in hill and mountain habitats in many parts of their range where turtles have invaded stock tanks, logging ponds, and other standing waters created by humans over the last century. Three areas, however, that show marked declines in populations are southern California from Baja up to Ventura; the Central Valley of California; and the northernmost populations in Washington State and, perhaps, in northern Oregon. Today, only isolated clusters of turtles remain in most of southern California (Brattstrom 1988), which now are separated by inhospitable areas of cities and roads. Also, these isolated populations occur in aquatic habitats that humans are drawn to, especially in the summer. Much of the natural habitat for the species in the Central Valley of California, especially the southern portion (San Joaquin Valley), has been eliminated. The original complex of lakes, rivers, streams, wetlands, and sloughs was estimated to cover at least 787,000 ha in the Central Valley (Harding 1960). Most of this habitat has been drained or channelized to support a massive agricultural system and urban centers; however, the species has not been extirpated from the San Joaquin Valley. There remain a number of areas in the valley that support relatively large populations of turtles with population structures that indicate successful reproduction and long-term stability (Germano and Bury 2001). Besides these areas, A. marmorata also appears to be uncommon in northernmost Oregon and into Washington State (Bury 1995; Hays et al. 1999).

Threats to Survival. - In the 19th and early 20th centuries, A. marmorata was exploited for food (Storer 1930; Buskirk 1990; Bettelheim 2005). This began as early as the 1860s (Lockington 1879) and commercial exploitation peaked in the $1890 \mathrm{~s}$. Smith (1895) noted that at least 18,000 turtles/year were sold in the markets in San Francisco. Records of the U.S. Bureau of Fisheries indicate that the catch peaked in 1897 at $48,534 \mathrm{~kg}(107,000$ pounds). In 1895 the catch was $42,638 \mathrm{~kg}$, consisting of approximately 63,000 animals. Collecting efforts in the 1880 s included the use of a small schooner operated on Tulare Lake (now a groundwater recharge facility and cropland) in the San Joaquin Valley, California. The commercial trade continued until at least the 1930s, and this activity exacerbated population declines caused by habitat losses and other factors.

Commercial overharvest of this species followed closely the pattern noted for the California red-legged frog, Rana draytonii (Jennings and Hayes 1985). Although there are no reliable estimates of the total take for pets, in the early 1960s, one of us (RBB) was asked by a reptile dealer in southern California to help collect this species. When asked for an approximate number to collect, the dealer replied that they had just exported 500 of this species to Europe, and needed that many additional turtles to fill orders. Collecting is now greatly reduced due to protective regulations.

Now and in the future, habitat destruction and alteration are the primary threats to the continued existence of this species. This is a problem that besets most species around the world. Massive water development projects have changed the location, flow, and use of water across much of the range of A. marmorata, particularly in the Central Valley of California. Construction of dams on many rivers results in cooler water temperatures and faster flowing water below dams, which may be detrimental to turtle populations (Reese and Welsh 1998a, b). Also, the reservoirs behind these dams may not be especially suitable habitat because recreational activities such as fishing, skiing, or swimming likely disturb normal behavioral routines of the turtles. Further, some of these reservoirs have large draw downs seasonally, which inhibits growth of aquatic vegetation and associated invertebrate populations that are prey for turtles. However, we have studied a population of A. marmorata in one large reservoir (Whiskeytown National Recreation Area in northern California) where we found turtles to be relatively abundant and the population was composed of a 
stable age distribution (R. Bury and D. Germano, unpubl. data). Elimination of water bodies of any kind reduces habitat for this species. Still, small impoundments with permanent or intermittent water are inhabited by turtles, and numbers can be quite high, particularly if vegetation (e.g., trees, tules, cattails) and basking sites are allowed to become established along shorelines (Cook and Martini-Lamb 2004).

Other impacts can have local effects on A.marmorata, but are not expected to have significant population consequences. Fire can cause mortality in turtles overwintering in terrestrial habitats, turtles are sometimes deliberately shot while basking, or are inadvertently caught while fishing. They also have to contend with predators and competitors in some situations, especially urban waters (Bury, in press). The native raccoon (Procyon lotor) can be a problem in situations where turtle habitat occurs in urban environments because of artificially high raccoon populations associated with supplemental food from human habitations (G. Rathbun, pers. comm.). The introduction and spread of the red-eared slider, a potential competitor, is occurring in California (Spinks et al. 2003; Patterson 2006) and the Pacific Northwest (Bury 1995, in press).

Conservation Measures Taken. - Actinemys marmorata is protected by state law within its entire native range: it is listed as State Endangered in Washington; Sensitive - Critical in Oregon, and a Species of Special Concern in California. However, none of these laws confer effective protection of the habitat. Some habitat is partly to fully protected in waters designated as Wild and Scenic Rivers, but these are relatively few. The turtle occurs in some state and federal parks at low elevations, including Humboldt Redwoods State Park (northern California), Point Reyes National Seashore (north of San Francisco) and Pinnacles National Monument (south of San Francisco). Some limited habitat occurs in wilderness areas, but many of these are located in montane or high-elevation localities (e.g., Yosemite National Park, California), and turtles are generally uncommon above $1200 \mathrm{~m}$. A small series of ponds at one site in southwestern Washington State are protected specifically for the turtle. The species was proposed for Federal listing as a threatened species, but it was found not warranted (U.S. Fish and Wildlife Service 1993).

Conservation Measures Proposed. - We believe that conservation efforts need to focus on protection of turtles in their native habitats. There have been attempts to translocate the species away from construction projects in California and Oregon, but none of the results have been published. This practice needs serious scrutiny. It is imperative to rigorously monitor the results of these efforts to evaluate the potential effectiveness of this mitigation strategy. Translocated turtles are known to return to the original site (L. Hunt, unpubl. data), which subjects them to increased stress and the likelihood of mortality.Additionally, this practice may mix stocks of genetically differentiated forms. Most attempts to translocate amphibians and reptiles have been ineffective as conservation strategies (Dodd and Seigel 1991).
Captive Husbandry. - There are successful efforts to captively breed this species in Washington, and to headstart young individuals for reintroduction into the wild in California, Oregon, and Washington. Except for rare instances, we question the expense of captive breeding of this species and point out that there are potential adverse effects (e.g., mixing gene pools) that need to be carefully considered before this is tried on other than an experimental basis. The long-term plight of the species must be considered in that these actions, if applied incorrectly, may dilute efforts to effectively protect and manage wild populations and their habitat.

Current Research. - Several meetings have been organized to discuss the status and needs of the species. For example, a workshop with 110 attendees on the biology and status of the turtle sponsored by the Western Section of The Wildlife Society was held in 2004 in northern California. A Western Pond Turtle Group was established in 1991 to foster communication and coordinate research on the species. Interested parties included representatives from federal and state agencies, several universities, zoos, industry, and private citizens. A primary goal of the Western Pond Turtle Group is to develop a strategic plan for the conservation of the turtle. Many members of this group are preparing a handbook on the species, including sampling protocol, summary of ecology, and management considerations. Recently, the California Department of Fish and Game commisioned a "Conservation Strategy" to summarize known information, identify threats, hold regional workshops, and other efforts for this turtle statewide.

Acknowledgments. - We thank Robert H. Goodman, Jeffery Lovich, Galen B. Rathbun, and the editors of this volume for their helpful comments on the manuscript. Daniel C. Holland greatly assisted on the first draft, but decided to withdraw as an author. We appreciate his input and efforts.

\section{LITERATURE CITED}

BAIRD,S.F.AND GIRARD,C. 1852.Descriptions of new species of reptiles collected by the U.S. Exploring Expedition under the command of Capt. Charles Wilkes. Proceedings National Academy Sciences Philadelphia 6:174-177.

BANTA, B.H. 1963. On the occurrence of Clemmys marmorata (Reptilia:Testudinata) in western Nevada. Wasmann Journal of Biology 21:75-77.

Bettelheim, M. 2005. Marmorata: the famed mud turtle of the San Francisco market. California History 82:26-42.

Bickham, J.W., Lamb, T., MinX, P., AND Patton, J.C. 1996. Molecular systematics of the genus Clemmys and the intergeneric relationships of emydid turtles. Herpetologica 52:89-97.

BlaCK, J.H. AND STORM, R. 1970. Notes on the herpetology of Grant County, Oregon. Great Basin Naturalist 15:9-12.

BRATTSTROM, B.H. 1988. Habitat destruction in California with special reference to Clemmys marmorata: a perspective. In: DeLisle, H.F. Brown, P.R., Kaufman, B., and McGurty, B.M. (Eds.). Proc. Conf. Calif. Herpetology. SW Herpetologist Society Special Publication 4,pp. 13-24.

Bury, R.B. 1970. Clemmys marmorata. Catalogue of American 
Amphibians and Reptiles: 100.1-100.3.

BuRY, R.B. 1972. Habits and home range of the Pacific Pond Turtle, Clemmys marmorata, in a stream community. Ph.D. Dissertation, University of California, Berkeley, 205 pp.

BuRY,R.B.1979.Population ecology of freshwater turtles.In: Harless, M. and Morlock,H.(Eds.). Turtles: Perspectives and Research.John Wiley and Sons, New York, pp. 571-602

BuRY, R.B. 1986. Feeding ecology of the turtle Clemmys marmorata. Journal of Herpetology 20:515-521.

BuRY, R.B. 1995. Western pond turtle: Clemmys marmorata (Baird and Girard). In: Storm, R.M. and Leonard, W.P. (Eds.). Reptiles of Washington and Oregon. Seattle Audubon Society, Washington, pp. 34-37.

BURY, R.B. In press. Do urban areas favor invasive turtles in the Pacific Northwest? In: Mitchell, J. C. and Brown, R. (Eds.). Urban Herpetology. Herpetological Conservation 3.

Bury, R.B. and Germano, D.J. 1998. Annual deposition of scute rings in the western pond turtle, Clemmys marmorata. Chelonian Conservation and Biology 3:108-109.

BURY, R.B. AND LUCKENBACH, R.A. 1977. Introduced amphibians and reptiles in California. Biological Conservation 10:1-14

BuRY, R.B. AND WolfHeIM, J.H. 1973. Aggression in free-living pond turtles (Clemmys marmorata). BioScience 23:659-662.

BUSKIRK, J.R. 1990. An overview of the western pond turtle, Clemmys marmorata.In:Beaman,K.R.,Caporaso,F.,McKeown,S., and Graff, M.(Eds.).Proceeding,First International Symposium on Turtles and Tortoises: Conservation and Captive Husbandry, pp. 16-23.

BuskiRK, J.R. 2002. The western pond turtle, Emys marmorata. Radiata 11:3-30.

CITES. 2007. Appendices I, II and III valid from 13 September 2007. www.cites.org/eng/app/index.shtml

CoOK, D.G. AND MARTINI-LAMB, J. 2004. Distribution and habitat use of Pacific pond turtles in a summer impounded river. Transactions of the Western Section of the Wildlife Society 40:84-89.

CARR, A. 1952. Handbook of Turtles: The Turtles of the United States, Canada and Baja California. Cornell University Press, Ithaca, NY, $542 \mathrm{pp}$.

CARY,W.M. 1889. Biennial report of the fish commissioner of the state of Nevada 1887-1888. Carson City, Nevada:3-7.

Collins,J.T. AND TAGGART,T.W.2002.Standard Common and Current Scientific Names for NorthAmericanAmphibians, Turtles, Reptiles \& Crocodilians. The Center for North American Herpetology, Lawrence, Kansas, $44 \mathrm{pp}$

DoDD, C.K., JR. AND SEIGEL, R.A. 1991. Relocation, repatriation and translocation of amphibians and reptiles: Are they conservation strategies that work? Herpetologica 47:336-350.

ERnst, C.H., Lovich. J.E., AND Barbour, R.W. 1994. Turtles of the United States and Canada.Smithsonian InstitutionPress, Washington and London, $578 \mathrm{pp}$.

Evenden, F.G. 1948. Distribution of turtles of western Oregon. Herpetologica 4:201-204.

Ewert, M.E., Jackson, D.R., AND Nelson, C.E. 1994. Patterns of temperature-dependent sex-determination in turtles. Journal of Experimental Zooloogy 270:3-15.

FELDMAN, M. 1982. Notes on reproduction in Clemmys marmorata. Herpetolocial Review 13:10-11.

FELDMAN,C.R. AND PARHAM, J.F. 2001. Molecular systematics of emydine turtles. Chelonian Conservation and Biology 4:224-228.

Feldman, C.R. AND PARHAM, J.F. 2002. Molecular phylogenetics of emydine turtles: taxonomic revision and the evolution of shell kinesis. Molecular Phylogenetics and Evolution 22:388-398.

FrITZ, U. AND HaVAS, P. 2007. Checklist of chelonians of the world. Vertebrate Zoology 57:149-368.

Germano, D.J. 2000. Occurrence of a colonial protozoan on the western pond turtle, Clemmys marmorata. Herpetological Natural History 7:67-71.

Germano, D.J., AND R.B. Bury. 1998. Age determination in turtles: evidence of annual deposition of scute rings. Chelonian Conserva- tion and Biology 3:123-132.

GERMANo, D.J., AND BuRY, R.B. 2001. Western pond turtles (Clemmys marmorata) in the Central Valley of California: status and population structure. Transactions of the Western Section of The Wildlife Society 37:22-36.

Germano, D.J. and Rathbun, G.B. In press. Growth, population structure, and reproduction of the Western Pond Turtle (Actinemys marmorata) on the central coast of California. Chelonian Conservation and Biology.

Goodman, R.H., JR. 1997a. The biology of the southwestern pond turtle (Clemmys marmorata pallida) in the Chino Hills State Park and the west fork of the San Gabriel River. M.S. Thesis, California State Polytechnic University, Pomona.

GoOdMAn, R.H., JR. 1997b. Occurrence of double clutching in the southwestern pond turtle, Clemmys marmorata pallida, in the Los Angeles Basin. Chelonian Conservation and Biology 2:419-420.

GOODMAN, R.H., JR. AND G.R. STEWART. 1998. Clemmys marmorata pallida (Southwestern pond turtle). Coprophagy. Herpetological Review 29:98.

Goodman, R.H., JR. And Stewart, G.R. 2000. Aquatic home ranges of female western pond turtles, Clemmys marmorata, at two sites in Southern California. Chelonian Conservation and Biology 3:743-745.

GRAY, E.M. 1995. DNA fingerprinting reveals a lack of genetic variation in northern populations of the western pond turtle(Clemmys marmorata). Conservation Biology 9:1244-1255.

GREGORY,P.T.ANDCAMPBELL,R.W.1984.ThereptilesofBritishColumbia. Handbook British Columbia Provincial Museum 44, 103 pp.

Hallowell, E. 1854. Descriptions of new reptiles from California. Proceedings National Academy of Sciences, Philadelphia 7:91-97.

HARDING, S.T. 1960. Water in Califomia. n-p Publications, Palo Alto, CA.

HAY, O.P. 1903. Two new species of fossil turtles from Oregon. University of California Publications, Bulletin of the Department of Geological Sciences 3:237-241.

HaYs,D.W.,McAllister, K.R., Richardson, S.A., andStinson,D.W. 1999. Washington State Recovery Plan for the Western Pond Turtle. Washington Department of Fish and Wildlife, 66 pp. www.wa.gov/ wdfw/wlm/diversty/soc/recovery/pondturt/wptfinal.pdf

HILL,P.M.2006.Actinemysmarmorata (Westernpondturtle): Neonates. Herpetological Review 37:76.

Holland, D.C. 1985a. An ecological and quantitative study of the western pond turtle (Clemmys marmorata) in San Luis Obispo County, California. M.A. Thesis, California State University Fresno.

Holland, D.C. 1985b. Western pond turtle (Clemmys marmorata): Feeding. Herpetological Review 16:112-113.

Holland, D.C. 1988. Western pond turtle (Clemmys marmorata): Behavior. Herpetological Review 19:87

HoLLAND, D.C. 1992. Level and pattern in morphological variation: a phylogeographic study of the western pond turtle (Clemmys marmorata). Ph.D. Dissertation, University of Southwestern Louisiana, Lafayette.

Holland, D.C. 1994. The Western pond turtle: Habitat and history. UnpublishedFinal Report.Portland,OR:U.S.Department of Energy, BonnevillePowerAdministration.www.efw.bpa.gov/environment/ ew/ewp/docs/reports/wildlife/w62137-1.pdf

Holman, J.A. AND Fritz, U. 2001. A new emydine species from the Middle Miocene (Barstovian) of Nebraska,USA with anew generic arrangement for the species of Clemmys sensu McDowell (1964) (Reptilia: Testudines: Emydidae). Zoologische Abhandlungen Staatliches Museum für Tierkunde Dresden 51:331-354.

IngLes, L.G. 1930. A new species of Telorchis from the intestine of Clemmys marmorata. Journal of Parasitology 17:101-103.

IUCN. 2007. 2007 IUCN Red List of Threatened Species. www. iucnredlist.org

IVERSON, J.B. 1986. A Checklist with Distribution Maps of Turtles of the World. Privately printed, Paust Printing, Richmond, Indiana, $282 \mathrm{pp}$. 
IVERSON, J.B. 1992.ARevised Checklist with Distribution Maps of the Turtles of the World. Richmond, IN: Privately Printed, $363 \mathrm{pp}$.

Iverson, J.B., Meylan, P.A., AND Seidel, M.E. 2008. TestudinesTurtles. In: Crother, B.I. (Ed.). Scientific and Standard English Names of Amphibians and Reptiles of North America North of Mexico. SSAR Herpetological Circular 37, pp. 67-74.

JENNINGS, M.R. 1987. Annotated checklist of the amphibians and reptiles of California.2ndEd.Southwestern Herpetological Society, Special Publication 3, 48 pp.

Jennings, M.R. And M.P. HaYes. 1985. Pre-1900 overharvest of the Californiared-leggedfrog(Ranaauroradraytonii):The inducementfor bullfrog (Rana catesbeiana) introduction. Herpetologica 41:94-103.

LARDIE, R.L. 1975. Notes on eggs and young of Clemmys marmorata marmorata (Baird and Girard). Occasional Papers, Museum of Natural History, University of Puget Sound 47:654.

LARIVERS, I. 1942. Some new amphibian and reptile records from Nevada. Journal of Entomology and Zoology 34:53-68.

Lockington, W.N. 1879. Notes on some reptiles and Batrachia of the Pacific Coast. American Naturalist 7:780-783.

Lovich, J. AND Meyer, K. 2002. The western pond turtle (Clemmys marmorata) in the Mojave River, California, U.S.A.: highly adapted survivor or tenuous relict? Journal of Zoology, London 256:537-545.

LOVICH, R.E.,AKRe, T.S.,BlackbuRn,J.,Robinson, T., ANd C.MAhrdT. 2007. Actinemys marmorata (Pacific pond turtle). Mexico: Baja California Norte. Herpetological Review 38:216-217.

LUBCKE, G.M. 2006. Actinemys marmorata (Pacific pond turtle). Size. Herpetological Review 37:339.

LUBCKE, G.M. AND WILSON, D. 2007. Variation in shell morphology of the western pond turtle (Actinemys marmorata Baird and Girard) from three aquatic habitats in Northern California. Journal of Herpetology 41:107-114.

Matsuda, B.M., Green, D.M., and Gregory, P.T. 2006. Amphibians and Reptiles of British Columbia. Royal British Columbia Museum Handbook. Victoria, BC, Canada, 266 pp.

MANNING, T. 1990. Summer feeding habits of river otter (Lutra canadensis) on the Mendocino National Forest, California. Northwestern Naturalist 71:38-42.

MoyLE, P.B. 1973. Effect of introduced bullfrogs, Rana catesbeiana, on the native frogs of the San Joaquin Valley, California. Copeia 1973:18-22.

Nussbaum,R.A.,Brodie,E.D.,JR.,ANDStorm,R.C.1983.Amphibians and Reptiles of the Pacific Northwest. University Press of Idaho, Moscow, ID, 322 pp.

Parham, J.F. AND C.R. Feldman. 2002. Generic revision of emydine turtles. Turtle and Tortoise Newsletter 6:28-30.

PATtERSON, L.C. 2006. Life history and ecology of an introduced population of red-eared sliders (Trachemys scripta elegans) in the Central Valley of California with implications for the conservation of the western pond turtle (Emys marmorata). M.S. Thesis, California State University, Sacramento.

PIRES,M.N.2001.Allocation of reproductive output in the western pond turtle (Clemmys marmorata) in southern California. M.S. Thesis, California State Polytechnic University, Pomona.

Rathbun, G.B.,SEIPEL, N., AND Holland,D.C. 1992.Nesting behavior and movements of western pond turtles, Clemmys marmorata. Southwestern Naturalist 37:319-324.

Rathbun, G.B., ScOtT, N.J., JR., AND MuRPhey, T.G. 2002. Terrestrial habitat use by Pacific pond turtles in a Mediterranean climate. Southwestern Naturalist 47:225-235.

REESE, D.A. AND WeLSH, H.H., JR. 1997. Use of terrestrial habitat by Western Pond Turtles, Clemmys marmorata: implications for management. In: Van Abbema, J. (Ed.). Proceedings: Conservation, Restoration, and Management of Tortoises and Turtles - An International Conference. New York Turtle and Tortoise Society, pp. 352-357.

REESE, D.A. AND Welsh, H.H., JR. 1998a. Habitat use by western pond turtles in the Trinity River, California. Journal of Wildlife
Management 62:842-853.

REESE,D.A. AND WELSH,H.H.,JR. 1998b.Comparative demography of Clemmys marmorata populations in the Trinity River of California in the context of dam-induced alterations. Journal of Herpetology 32:505-515.

SEeLIGER, L.M. 1945. Variation in the Pacific mud turtle, Clemmys marmorata. Copeia 1945:150-159.

SLATER, J.R. 1962. Variations and new range of Clemmys marmorata. Occasional Papers, Museum of Natural History,University of Puget Sound 20:204-205.

SMITH, H.M. 1895. Notes on a reconnaissance of the fisheries of the Pacific coast of the United States in 1894. Bulletin U.S. Fisheries Commission 14:223-288.

SMIth, H.M. AND SMIth, R.B. 1979. Synopsis of the Herpetofauna of Mexico. Vol. VI. Guide to Mexican Turtles. Johnson, North Bennington, Vermont, $1044 \mathrm{pp}$.

SPINKS, P.Q. AND SHAFFER, H.B. 2005. Range-wide molecular analysis of the western pond turtle (Emys marmorata): cryptic variation, isolation by distance, and their conservation implications. Molecular Ecology 14:2047-2064.

Sinks, P.Q., Pauly, G.B., Crayon, J.J., and Shaffer, H.B. 2003. Survival of the western pond turtle (Emys marmorata) in an urban California environment. Biological Conservation 113:257-267.

STEBBINS,R.C.2003.AFieldGuide to WesternReptiles andAmphibians. Houghton-Mifflin Co., Boston, MA, 533 pp.

STEPHENS, P.R. AND WIENS, J.J. 2003. Ecological diversification and phylogeny of emydid turtles. Biological Journal of the Linnean Society 79:577-610.

STORER, T.I. 1930. Notes on the range and life-history of the Pacific fresh-water turtle, Clemmys marmorata. University of California, Publications in Zooloogy 32:429-441.

STRAUCH,A.1862.Chelonologischestudien, mitbesondererbeziehung auf die Schildkrotensammlung der kaiserlichen Akademie der Wissenschaften zu St. Petersburg. Mem. Acad. Imp. Sci. St. Petersburg. (7)5:1-196.

THATChER, V.E. 1954. Helminth parasites of the Pacific terrapin Clemmys marmorata (Baird and Girard). M.A. Thesis, Oregon State University, Corvallis.

Turtle TaXonomy Working Group [Bickham, J.W., Iverson, J.B., Parham, J.F., Philippen, H.D., Rhodin, A.G.J., Shaffer, H.B., Spinks, P.Q., and van Dijk, P.P.]. 2007. An annotated list of modern turtle terminal taxa with comments on areas of taxonomic instability and recent change. In: Shaffer, H.B., FitzSimmons, N.N., Georges, A., and Rhodin, A.G.J. (Eds.). Defining Turtle Diversity: Proceedings of a Workshop on Genetics, Ethics, and Taxonomy of FreshwaterTurtles and Tortoises. Chelonian Research Monographs No. 4, pp. 173-199.

U.S. Fish and WildLifE SERVICE. 1993. Endangered and Threatened wildlife and plants; notice of 1-year petition finding on the Western Pond Turtle. 50 CFR, Part 17; 58(153):42717-42718.

Vogt, R.C., AND Bull, J. J. 1982. Temperature controlled sexdetermination in turtles: ecological and behavioral aspects Herpetologica 38:158-164.

WELSH,H.H.1988.Anecogeographic analysis of the herpetofauna of the Sierra San Pedro Martir region, Baja California, with a contribution tothe biogeography of the BajaCaliforniaherpetofauna.Proceedings of the California Academy of Sciences 46:1-72.

\section{Citation Format for this Account:}

BuRY, R.B. AND GERMAno, D.J. 2008. Actinemys marmorata (Baird and Girard 1852) - western pond turtle, Pacific pond turtle. In: Rhodin, A.G.J., Pritchard, P.C.H., van Dijk, P.P., Saumure, R.A., Buhlmann, K.A., and Iverson, J.B. (Eds.). Conservation Biology of Freshwater Turtles and Tortoises: A Compilation Project of the IUCN/SSC Tortoise and Freshwater Turtle Specialist Group. Chelonian Research Monographs No. 5,pp.001.1-001.9, doi:10.3854/ crm.5.001.marmorata.v1.2008, http://www.iucn-tftsg.org/cbftt. 